DOI: https://doi.org/10.47405/mjssh.v6i5.800

\begin{tabular}{|c|c|}
\hline$x_{i=1}$ & Malaysian Journal of Social Sciences and Humanities (MJSSH) \\
\hline Malaysian Jounal of & Volume 6, Issue 5, May 2021 \\
\hline (MJ-ssH) & e-ISSN : 2504-8562 \\
\hline & $\begin{array}{l}\text { Journal home page: } \\
\text { www.msocialsciences.com }\end{array}$ \\
\hline
\end{tabular}

\title{
Hubungan antara Bidang Tugas dan Hubungan Sosial dengan Penjenamaan Semula Pengurusan Tingkatan Enam
}

\author{
Wee Fwen Yep ${ }^{1}$, Abdul Said Bin Ambotang ${ }^{1}$ \\ 1Fakulti Psikologi dan Pendidikan, Universiti Malaysia Sabah (UMS) \\ Correspondence: Ween Fwen Yep (fywee@yahoo.com)
}

\begin{abstract}
Abstrak
Penjenamaan semula tingkatan enam merupakan inisiatif Kementerian Pendidikan Malaysia (KPM) dalam Pelan Pembangunan Pendidikan Malaysia (PPPM) 2013 - 2025 untuk memperkasa pendidikan tingkatan enam. Kajian ini bertujuan untuk mengkaji hubungan antara bidang tugas harian guru tingkatan enam dan hubungan sosial antara guru-guru dengan penjenamaan semula pengurusan tingkatan enam di Bahagian Sandakan, Sabah. Sampel kajian terdiri daripada 120 orang guru tingkatan enam dipilih daripada populasi seramai 169 orang guru tingkatan enam daripada 12 buah sekolah yang mempunyai tingkatan enam di Bahagian Sandakan. Sekolah tersebut terletak di daerah Sandakan, Beluran, Kinabatangan dan Telupid. Sampel dipilih dengan menggunakan prosedur pensampelan rawak mudah. Sementara itu, borang soal selidik digunakan sebagai instrumen kajian untuk mendapatkan data. Data dianalisis dengan menggunakan perisian IBM Statistical Package for Social Sciences (SPSS). Korelasi Pearson digunakan untuk mengukur kekuatan hubungan antara dua pemboleh ubah yang dikaji. Didapati ujian Korelasi Pearson menunjukkan terdapat korelasi sederhana, positif dan signifikan iaitu $\mathrm{r}=.492$ dan $\mathrm{p}=.000$ antara bidang tugas harian guru tingkatan enam dengan penjenamaan semula pengurusan tingkatan enam. Manakala ujian Korelasi Pearson antara hubungan sosial antara guru di sekolah dengan penjenamaan semula pengurusan tingkatan enam menunjukkan korelasi sangat lemah, negatif dan tidak signifikan iaitu $r=-.060$ dan $p=.517$. Hal ini menunjukkan guru tingkatan enam di Bahagian Sandakan dapat melaksanakan perubahan bidang tugas harian guru tingkatan enam. Selain itu, mereka berusaha memelihara hubungan baik dengan pentadbir sekolah aliran perdana dan rakan-rakan guru aliran perdana di sekolah. Hal ini, dapat merealisasikan kejayaan transformasi tingkatan enam melalui penjenamaan semula tingkatan enam.
\end{abstract}

Kata kunci: bidang tugas, hubungan sosial, penjenamaan semula, tingkatan enam

\section{The Relationship between Daily Duties and Social Relationships with Rebranding of Form Six Management}

\begin{abstract}
The rebranding of form six is an initiative of the Ministry of Education Malaysia (MOE) in the Malaysia Education Development Plan (PPPM) 2013 - 2025 to strengthen form six education. This study aims to examine the relationship between the daily duties of form six teachers and social relationships among teachers with rebranding of form six management in Sandakan division. The research sample consisted of 120 form six teachers selected from a population of 169 form six teachers from 12 schools which offer form six classes in the Sandakan division. The schools are located in the districts of Sandakan, Beluran, Kinabatangan and Telupid. Samples were selected using a simple
\end{abstract}


random sampling procedure. Meanwhile, a questionnaire was used as a research instrument to obtain data. Data were analyzed using IBM Statistical Package for Social Sciences (SPSS) version 22. Pearson correlation was used to measure the strength of the relationship between the two variables. It was found that the Pearson correlation test showed that there was a moderate, positive and significant correlation, $r=.492$ and $p=.000$ between the daily duties of form six teachers with the rebranding of form six management. While the Pearson correlation test between social relationships among teachers in school with the rebranding of form six management showed a very weak, negative and insignificant correlation, $\mathrm{r}=-.060$ and $\mathrm{p}=.517$. This shows that form six teachers in the Sandakan division can implement changes in the daily duties of form six teachers. In addition, they strive to maintain good relations with mainstream school administrators and fellow mainstream teachers in the school. This, can realize the success of form six transformation through the rebranding of form six.

Keywords: daily duties, form six, rebranding, social relationships

\section{Pengenalan}

Penjenamaan semula tingkatan enam yang lebih bercirikan sistem universiti termasuk pembelajaran berbentuk kuliah dan tutorial telah diperkenalkan pada tahun 2008. Langkah penjenamaan semula pengurusan tingkatan enam merupakan salah satu strategi untuk menaikkan taraf tingkatan enam agar selaras dengan statusnya sebagai pendidikan prauniversiti yang berperanan melengkapkan diri pelajar yang bakal menuntut ilmu dalam persekitaran institusi pengajian tinggi (Kementerian Pelajaran Malaysia, 2008).

Mulai tahun 2008, langkah penambahbaikan dari segi pengurusan, fungsi guru tingkatan enam dan kebajikan pelajar diberi tumpuan. Matlamat yang ingin dicapai adalah menjadikan proses pengajaran dan pembelajaran tingkatan enam lebih menarik dan kemas kini serta menonjolkan suasana pembelajaran ala universiti yang kondusif. Cadangan penambahbaikan yang disarankan oleh Kementerian Pelajaran Malaysia pada tahun 2008 merangkumi beberapa aspek seperti pengurusan dan pentadbiran, pelaksanaan pengajaran dan pembelajaran, penyelidikan dan penulisan ilmiah, kemudahan fizikal serta peranan Jabatan Pelajaran Negeri dan Pejabat Pelajaran Daerah.

Dalam aspek pengurusan dan pentadbiran mengikut Surat Pekeliling Ikhtisas KPM (2009), jawatan penolong kanan tingkatan enam diwujudkan untuk menguruskan semua hal ehwal pelajar tingkatan enam yang berkaitan dengan pentadbiran, kurikulum, kebajikan dan kokurikulum. Selain itu, pihak sekolah perlu menyediakan suasana pembelajaran tingkatan enam yang lebih bersifat berdikari dan kondusif. Sementara itu, Setiap guru akademik perlu diperuntukkan sekurang-kurangnya 16 waktu PdP, 4 waktu untuk kokurikulum dan perlu menjadi guru penasihat dan 4 waktu kerja kursus. Seterusnya, profesionalisme guru ditingkatkan dengan memilih guru yang mempunyai opsyen yang sesuai dengan mata pelajaran yang ditawarkan (Surat Pekeliling Ikhtisas, 2009).

Kemahiran guru dalam membuat penyelidikan dan penulisan ilmiah merupakan ciri-ciri penting dalam pengajaran dan pembelajaran. Oleh itu, sesi penyelidikan melatih pelajar dalam kemahiran mencari bahan, mengekstrak isi-isi penting daripada karya-karya yang disorot dan menganalisis isi kandungan tersebut mengikut pandangan penyelidik. Maka, penyelidikan dijadikan satu amalan utama bagi guru tingkatan enam agar tugasan mereka setara dengan pensyarah di pusat pengajian tinggi. Selain itu, pelbagai pendekatan dan kaedah seperti kuliah dan tutorial diperkenalkan serta pelaksanaan waktu pengajaran yang lebih fleksibel dan selaras dengan keperluan sukatan pelajaran mengikut semester (Surat Pekeliling Ikhtisas KPM, 2009).

Sementara itu, dalam aspek pembelajaran dan pemudahcaraan $(\mathrm{PdPc})$, pelajar prauniversiti adalah berada dalam fasa peralihan daripada pedagogi kepada andragogi iaitu daripada pendekatan PdPc berorientasikan kandungan pelajaran dan berpusatkan guru kepada pembelajaran terarah kendiri yang berterusan (Ashari, 2011). Hal ini merujuk pelajar tingkatan enam mengikuti pengajian sistem modular yang memerlukan pendekatan andragogi. Selain itu, dari aspek kokurikulum pula, aktiviti 
kokurikulum yang ditawarkan untuk pelajar dalam penjenamaan semula tingkatan enam adalah suatu aktiviti yang boleh membentuk ciri-ciri kepimpinan dan ketrampilan pelajar (Surat Pekeliling Ikhtisas, 2009).

Seterusnya, setiap guru tingkatan enam termasuk guru penolong kanan tingkatan enam dikehendaki menyediakan empat folio bagi tujuan pemantauan iaitu folio pengajaran dan pembelajaran, folio penyelidikan, folio penilaian dan pentaksiran serta folio kokurikulum. Kandungan folio ini akan menjadikan bahan pemantauan oleh pihak pentadbir untuk menilai prestasi guru tingkatan enam. Selain itu, guru tingkatan enam yang menjawat gred jawatan yang tertinggi seperti DG 52 atau DG 48 perlu memegang jawatan khas seperti Setiausaha Peperiksaan Sekolah, Ketua Penyelidikan, Ketua Unit Mata Pelajaran Tingkatan Enam serta Ahli Jawatankuasa Majlis Kurikulum Sekolah.

\section{Pernyataan Masalah Kajian}

Lantikan guru tingkatan enam telah menyebabkan perubahan dari aspek bidang tugas dan beban tugas. Bagi guru yang memilih untuk kenaikan pangkat, sudah tentu lantikan sebagai guru akademik tingkatan enam bagaikan durian runtuh. Guru yang terpilih berpeluang menikmati gred jawatan lebih tinggi dan bayaran saraan yang lebih baik atau ganjaran. Menurut Philip (1995), skim yang menarik dapat meningkatkan motivasi dan komitmen pekerja yang yang bukan diberikan sekali atau "one-off". Kenyataannya disokong oleh Ab. Aziz (2002), menyatakan pekerja bekerja untuk memuaskan pelbagai keperluan dan kepuasan kewangan merupakan salah satu daripadanya. Justeru itu kepuasan kewangan merupakan satu variabel penting dalam usaha peningkatan kepuasan dan produktiviti pekerja. Walau bagaimanapun, segelintir guru yang sudah menerima surat lantikan memilih untuk merayu supaya dikembalikan status quo kerana lanjutan masa bekerja hingga petang yang menyebabkan kepenatan di kalangan guru dan pelajar dan keperluan menyediakan dokumentasi tertentu, terutama penyelidikan.

Perubahan penjenamaan semula tingkatan enam melibatkan PdPc tahap prauniversiti. Kegagalan mengadakan latihan guru tingkatan enam untuk perlaksanaan PdPc tahap prauniversiti melalui kursus, bengkel dan latihan serta pemantauan yang tidak rapi bagi slot penyelidikan guru telah menunjukkan kelemahan dalam pengurusan tingkatan enam. Menurut Gold dan Roth (1993), perubahan dalam penstrukturan dan pengurusan organisasi secara mendadak akan meningkatkan kekeliruan dan tekanan kepada subordinat.

Kewujudan pengurusan tingkatan enam telah mengundang sub budaya yang tidak sihat. Sebagai contoh, pemisahan pentadbiran antara tingkatan enam dan aliran perdana mengundang tafsiran-tafsiran yang negatif serta berupaya mengeruhkan hubungan antara guru dan pihak pentadbiran. Kewujudan perjawatan guru akademik tingkatan enam (GAT6) DG 44, DG 48, dan DG 52 dilihat menjadi idaman kepada ramai guru bukan sahaja yang pernah mengajar tingkatan enam malah yang tidak pernah mengajar pun turut berminat. Walau bagaimanapun, dalam proses memperakui GAT6, pihak Bahagian Pengurusan Sumber Manusia (BPSM) mempunyai syarat tertentu bagi memilih GAT6 yang benarbenar layak. Justeru, ramai yang tidak dapat. Maka timbul ulasan-ulasan dan kritikan terhadap GAT6 yang diperakukan oleh pihak BPSM.

Tambahan pula, Guru-guru tingkatan enam yang mengendalikan aktiviti kokurikulum di peringkat tingkatan enam masih perlu dilibatkan dalam aktiviti kokurikulum dalam aliran perdana seperti sukan tahunan sekolah dan "dipinjam" untuk melatih atau membimbing pelajar aliran perdana dalam aktiviti tertentu berdasarkan kepakaran guru. Hal ini menyebabkan guru tingkatan enam tidak dapat fokus sepenuhnya terhadap aktiviti kokurikulum tingkatan enam. Memandangkan aktiviti pelajar tingkatan enam adalah berbeza dengan arus perdana dan pengurusan kokurikulum tingkatan enam adalah dipisahkan daripada arus perdana menyebabkan beberapa salah faham timbul dan hubungan antara rakan sejawat mulai bermasalah. 


\section{Objektif Kajian}
Kajian ini adalah untuk:
i. Mengenal pasti hubungan antara bidang tugas harian guru tingkatan enam dengan penjenamaan semula pengurusan tingkatan enam.
ii. Mengenal pasti hubungan antara hubungan sosial antara guru-guru dengan penjenamaan semula pengurusan tingkatan enam.

\section{Tinjauan Literatur}

\section{Teori Z}

Teori Z dicipta oleh William Ouchi (1981). Menurut Ouchi, rahsia kejayaan Jepun bukanlah teknologi, tetapi cara khas mengurus manusia. Menurut Afid (2014), Teori ini merupakan teori perniagaan dan sudah banyak dipraktikkan di Amerika Syarikat dan Jepun dalam bidang ekonomi. Teori Z adalah lebih menekankan peranan pentadbir yang dapat membuat para pekerja menjadi selamat, selesa, senang dan merasa menjadi bahagian penting dalam perniagaan. Dengan demikian, pekerja akan bekerja dengan lebih efektif dan efisien dalam melakukan pekerjaannya. Cara kerja dan keberhasilan teori $\mathrm{Z}$ berpontensi menjana keberhasilan dalam bidang pendidikan.

Teori $\mathrm{Z}$ merupakan pendekatan pengurusan yang menggabungkan falsafah pengurusan budaya Jepun dan budaya Amerika. Teori $\mathrm{Z}$ juga menekankan perkembangan hubungan kepercayaan "trust relationship" antara pemimpin dan pekerja. Teori Z melihat pengambilan keputusan kolektif telah memberikan dorongan sosial yang diperlukan bagi mencapai hasil yang diperlukan. Dengan mengakui prestasi individu, maka pekerja bebas bekerja menggunakan potensi yang dimilikinya. Tambahan pula pekerja menjadi setia dan taat terhadap organisasi kesan daripada pengambilan keputusan dilakukan dengan cara bersama atau secara terbuka.

Justeru berdasarkan amalan daripada teori $\mathrm{Z}$, konsep yang dilihat boleh diaplikasikan dalam menjana keberhasilan penjenamaan semula pengurusan tingkatan enam. Pentadbir memposisikan diri sebagai motivator yang memberikan semangat kepada guru agar memiliki keinginan untuk mencungkil potensi individu dan memberikan penghargaan kepada sumbangan guru melalui amalan terbaik guru untuk berinovasi sesuai dengan minat dan potensi mereka tanpa ada paksaan. Seterusnya dapat memberikan sumbangan dalam peningkatan pencapaian sekolah dalam bidang akademik dan kokurikulum.

\section{Teori Dua Faktor Herzberg}

Teori Dua Faktor juga dikenali sebagai teori motivasi Herzberg atau teori hygiene-motivator. Teori ini diperkenalkan oleh Frederick Irving Herzberg pada tahun 1959, seorang ahli psikologi yang berasal dari Amerika Syarikat. Beliau merupakan seorang pakar dalam bidang pengurusan dan motivasi. Teori dua faktor atau two-factor theory terdiri daripada dua bahagian. Satu dipanggil faktor hygiene (kesihatan) dan kedua dipanggil faktor motivator (Herzberg, 1966). Herzberg menyatakan kedua-dua faktor ini tidak bersandaran antara satu sama lain. Beliau menyatakan bahawa faktor motivator tinggi akan menjadi penyebab kepada kepuasan hati yang tinggi dan dikenali sebagai faktor perangsang atau dikenali juga sebagai motivasi dalaman. Faktor motivator meliputi pencapaian, pengiktirafan terhadap pencapaian, kerja itu sendiri, tanggungjawab, kenaikan pangkat dan pertumbuhan. Manakala faktor hygiene dikenali sebagai faktor luaran. Faktor ini tidak mengarah kepada kepuasan positif untuk jangka panjang. Tetapi jika faktor-faktor ini tidak hadir, maka akan muncul ketidakpuasan. Faktor ini adalah faktor ekstrinsik untuk bekerja. Faktor hygiene adalah faktor yang diperlukan untuk menghindari ketidakpuasan. Faktor hygiene meliputi gaji, polisi organisasi, penyeliaan, keadaan pekerjaan, jaminan pekerjaan dan hubungan interpersonal.

Menurut Fatimah (2014), Kehadiran faktor perangsang atau motivator di tempat kerja seperti kenaikan pangkat, tanggungjawab, kerja itu sendiri, pertumbuhan, peningkatan dan pengiktirafan terhadap pencapaian akan memuaskan hati atau memotivasikan pekerja. Namun begitu, sekiranya mereka tiada, 
ia tidaklah melibatkan pekerja-pekerja tidak berpuas hati dan tidak mempunyai motivasi untuk memberikan prestasi yang baik dalam pekerjaan mereka. Sebaliknya kehadiran faktor kesihatan atau hygiene seperti polisi organisasi, penyeliaan, hubungan interpersonal, keadaan pekerjaan, gaji dan jaminan pekerjaan tidak pula menyebabkan pekerja puas hati tetapi sekiranya ini tiada, ketidakpuasan akan berlaku. Pendek kata, faktor perangsang atau motivator boleh dikenali sebagai faktor yang akan menyebabkan kepuasan bekerja, manakala faktor kesihatan atau hygiene lebih dikenali sebagai faktor ketidakpuasan.

\section{Rajah 1: Model Dua Faktor Herzberg}

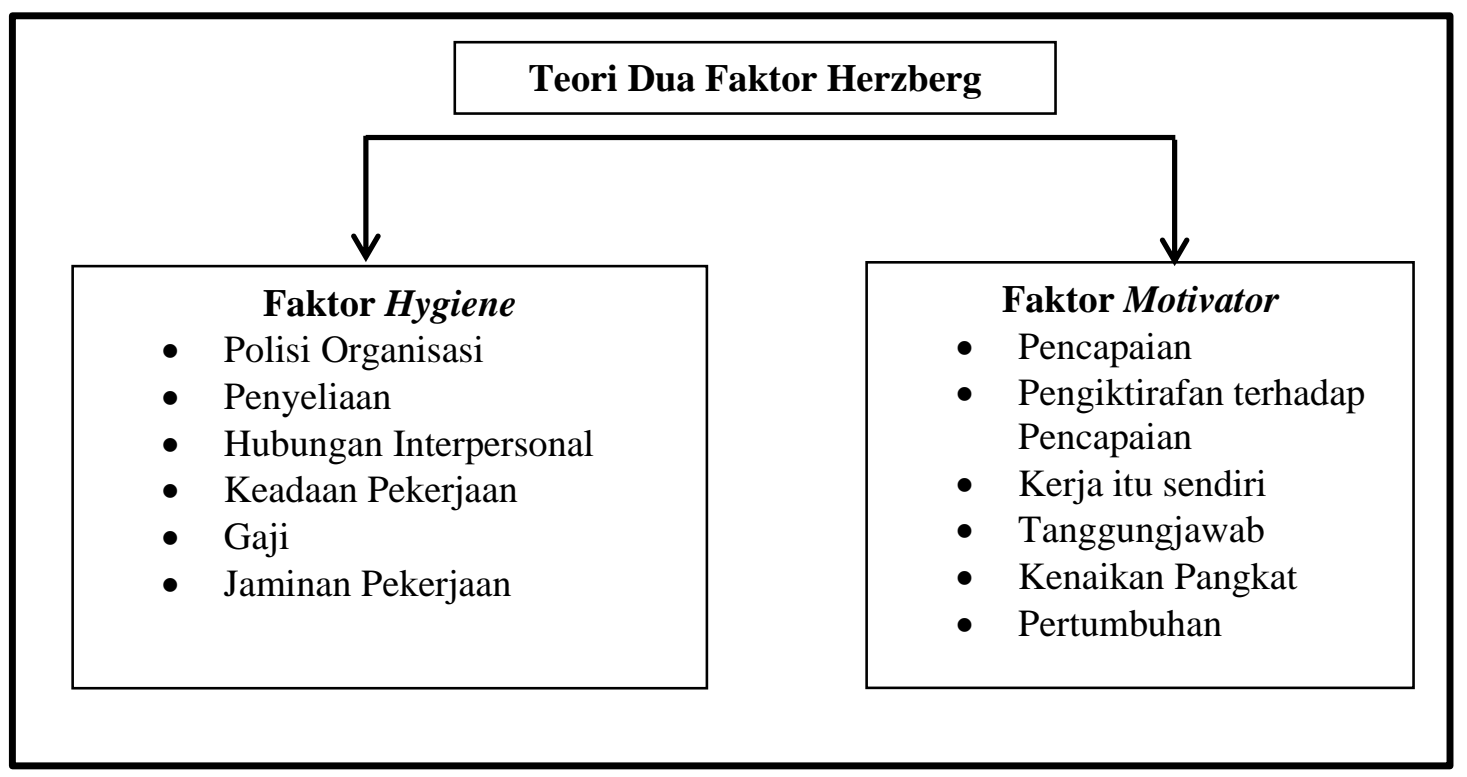

Sumber : Fatimah Affendi (2014)

Justeru berdasarkan amalan daripada teori dua faktor, konsep yang dilihat boleh dikaitkan dengan bidang tugas serta hubungan sosial. Penjenamaan semula pengurusan tingkatan enam dilihat telah menyebabkan perubahan pada bidang tugas guru dan menyebabkan pertambahan beban tugas tetapi guru berpeluang menikmati gred jawatan lebih tinggi dan bayaran saraan yang lebih baik atau ganjaran. Dua pemboleh ubah boleh dikaitkan dengan ganjaran berdasarkan faktor motivator dan faktor hygiene. Pemboleh ubah dalam faktor motivator yang boleh dikaitkan adalah peluang kenaikan pangkat manakala dalam faktor hygiene pula, pemboleh ubah yang terlibat ialah gaji. Faktor-faktor ini merupakan pemboleh ubah bebas yang dapat meningkatkan kepuasan kerja guru supaya sepadan dengan beban tugas guru. Kedua-dua faktor tersebut disokong oleh dapatan kajian daripada Kim dan Tang (2008), menunjukkan kepuasan kerja yang tinggi dengan upah dan peluang kenaikan pangkat. Selain itu, dalam faktor hygiene pula, pemboleh ubah yang terlibat ialah hubungan interpersonal rakan sekerja yang baik dapat mengekalkan kepuasan bekerja.

\section{Model Produktiviti 3 POP}

Model produktiviti 3 POP diperkenalkan oleh Musabbir Chowdhury (2013). Beliau merupakan penasihat kanan produktiviti (Senior Productivity Consultant) di Collins Barrow, Toronto, Kanada dan merupakan pengurus program produktiviti di Kolej Perniagaan Niagara (Niagara College Business School). Three Pillars of Productivity (3 POP) Model merupakan model produktiviti yang melibatkan 3 elemen yang saling bersandaran iaitu strategi, operasi dan teknologi. Ketiga-tiga elemen ini perlu seiring dan selaras untuk meningkatkan produktiviti syarikat. Sekiranya, salah satu elemen tidak seiring atau wujud konflik, syarikat perlu mengubah operasinya bukan strateginya dalam melaksanakan program produktiviti. Dari aspek teknologi, contohnya peralatan dan bahan untuk membina rumah. Kontraktor perlu memilih teknologi yang betul untuk melaksanakan projek dengan baik supaya produktiviti dapat ditingkatkan. Mengenal pasti teknologi untuk melaksanakan sesuatu projek adalah tidak mudah, tetapi strategi yang seiring dengan operasi akan menyebabkan pemilihan teknologi menjadi lebih mudah. Saranan beliau mengingatkan matlamat "goal" adalah mencapai 
kelebihan terhadap pesaing bukan sentiasa berada di tahap yang sama dengan pesaing. Pengurus harus sentiasa memantau pasaran untuk tujuan inovasi dan bersedia bertindak terhadap perubahan.

Keselarasan kombinasi strategi, operasi, dan teknologi akan menyokong peningkatan produktiviti. Syarikat juga perlu ada budaya mengurus perubahan, toleransi terhadap kegagalan dan sedia menghadapi risiko. Syarikat yang produktif menunjukkan fleksibiliti terhadap peranan pekerja dan pekerja memiliki mentaliti untuk memajukan syarikat untuk meningkatkan produktiviti. Justeru, perkara pertama syarikat harus lakukan ialah budaya mengurus perubahan perlu ada pada pengurus dan pekerja untuk menyelaras kombinasi strategi, operasi dan teknologi bagi meningkatkan produktiviti.

\section{Rajah 2: Model Produktiviti 3 POP}

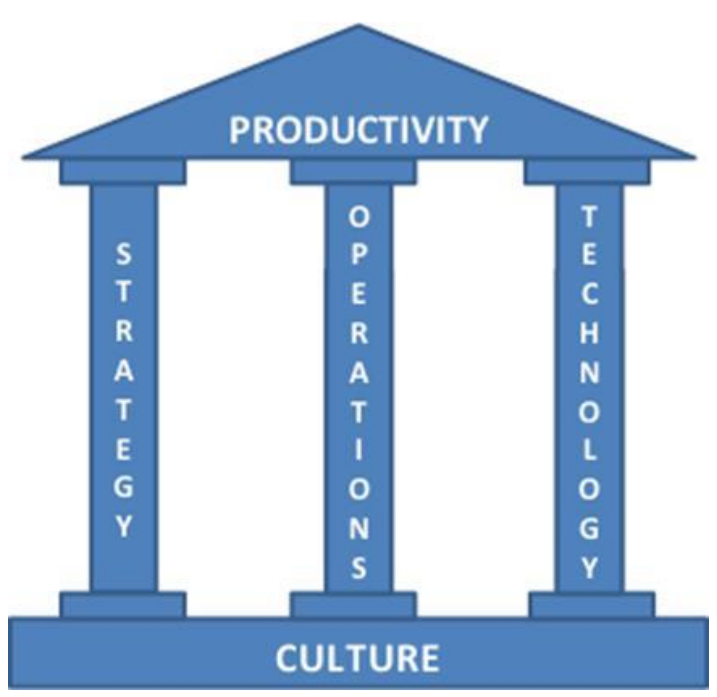

Sumber: Musabbir Chowdhury (2013)

Oleh itu, berdasarkan amalan dalam Model Produktiviti 3 POP yang melibatkan 3 elemen iaitu strategi, operasi dan teknologi yang perlu diselaraskan untuk meningkatkan produktiviti. Ketiga-tiga strategi ini berpotensi diaplikasikan dalam keberhasilan penjenamaan semula pengurusan tingkatan enam. Strategi adalah memantapkan pendidikan tingkatan enam dengan meningkatkan imej, sistem dan kualiti pendidikan ini setanding dengan pendidikan prauniversiti yang lain seperti di kolej-kolej matrikulasi dan pusat asasi sains. Operasi dalam penjenamaan semula tingkatan enam dengan mengumpul dan menempatkan secara berpusat pelajar tingkatan enam, menggunakan pakaian yang berbeza dengan pakaian sekolah harian biasa, menggunakan jadual waktu yang berbeza, tenaga pengajar khusus dan diletakkan dalam kategori yang berlainan berbanding dengan sekolah arus perdana, pembudayaan penyelidikan guru dan pelajar, dan bimbingan kepimpinan pelajar melalui aktiviti kokurikulum. Manakala dari aspek teknologi pula, pembangunan infostruktur terutamanya bagi peralatan ICT dan capaian Internet di pusat tingkatan enam perlu disegerakan supaya sesuai dengan kaedah pembelajaran berpusatkan pelajar dan perubahan dalam struktur pentaksiran STPM, daripada sistem terminal kepada sistem modular.

\section{Model Kurt Lewin}

Model Kurt Lewin boleh dikaitkan dengan perubahan yang dibawa melalui penjenamaan semula tingkatan enam. Teori dan prinsip pengurusan perubahannya dalam model ini bertujuan untuk penambahbaikan kualiti dan produktiviti sesebuah organisasi (Bernard, 2004). Sekiranya kita mempunyai seketul ais yang berbentuk segi empat sama dan kita ingin menukarkan bentuk asalnya kepada bentuk segi tiga, apakah yang perlu kita lakukan? Langkah pertama "Unfreeze", kita perlu cairkan ais tesebut untuk membolehkan kita menukar bentuknya. Langkah kedua "Change", kita perlu memenuhi cecair ais itu ke dalam bekas yang memiliki bentuk yang kita ingin tukarkannya. 
DOI: https://doi.org/10.47405/mjssh.v6i5.800

Seterusnya, langkah ketiga "Refreeze", kita perlu membekukan semula air dalam bekas baru supaya air itu boleh membeku menjadi ais semula.

Rajah 3: Contoh proses perubahan berdasarkan teori Kurt Lewin

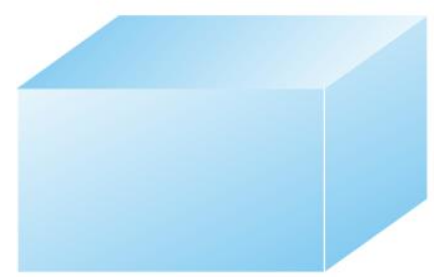

Ais berbentuk segi empat sama

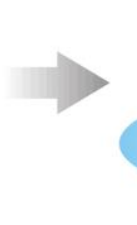

Dicairkan

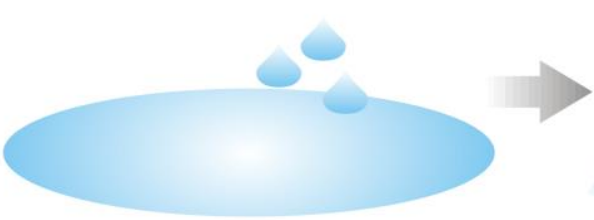

Dibekukan semula menjadi ais berbentuk segi tiga

Berdasarkan eksperimen di atas, kita boleh membuat kesimpulan bahawa kita perlu melalui prosedur yang betul sekiranya kita ingin melakukan sebarang perubahan untuk mengelakkan sebarang masalah atau keadaan menjadi lebih teruk daripada keadaan sedia ada. Untuk membuat sebarang perubahan yang berjaya, kita perlu memahami mengapa perubahan tersebut perlu dilakukan terlebih dahulu. Lewin menyatakan bahawa "Motivation for change must be generated before change can occur". Yang mana motivasi terhadap sebarang perubahan harus digenerasikan terlebih dahulu sebelum perubahan tersebut mengambil tempat. Banyak perkara yang telah diubah sejak teori Kurt Lewin ini diungkapkan pada tahun 1947, tetapi teori asli inilah yang masih diguna pakai dan dikatakan paling relevan (Bernard, 2004). Kurt Lewin mengembangkan model tiga tahap dari perubahan yang direncanakan yang mana menjelaskan bagaimana memulai, mengelola dan menstabilkan proses perubahan. Ketiga-tiga tahap tersebut adalah mencairkan "unfreezing", mengubah "changing" dan membekukan kembali "refreezing" (Bernard, 2004).

\section{Rajah 4: Tiga Tahap Perubahan Teori Kurt Lewin}

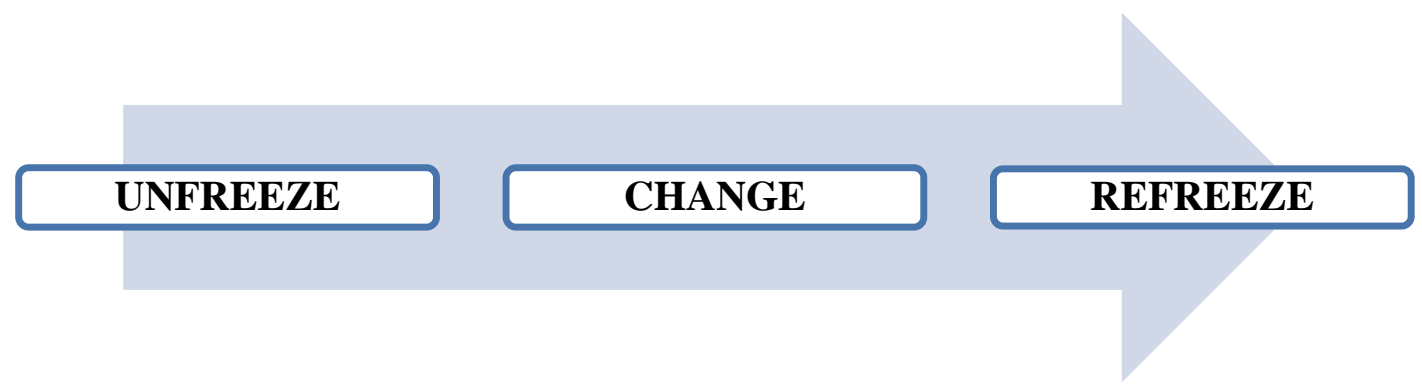

Dalam konteks penjenamaan semula pengurusan tingkatan enam, perubahan yang ditekankan adalah penjanaan keberhasilan pelajar dari segi penerapan budaya penyelidikan pelajar, kepimpinan pelajar yang dibimbing melalui aktiviti kokurikulum dan pencapaian akademik dalam sistem modular yang mirip dengan sistem di universiti yang membabitkan tiga semester.

\section{Metod Kajian}

Kajian ini berbentuk tinjauan. Seterusnya, sampel terdiri daripada guru-guru tingkatan enam yang melibatkan penolong kanan tingkatan enam, Guru akademik tingkatan enam dan guru kokurikulum tingkatan enam. Berdasarkan sumber Jabatan Pendidikan Negeri (JPN) Sabah tahun 2014, terdapat seramai 169 orang populasi guru tingkatan enam dari 12 sekolah yang mempunyai tingkatan enam di Bahagian Sandakan yang melibatkan daerah Sandakan, Beluran, Kinabatangan dan Telupid.

Dalam kajian ini penyelidik telah memilih untuk merujuk jadual penentuan saiz sampel yang dikemukakan oleh Krejcie dan Morgan (1970) untuk mendapatkan jumlah sampel yang diperlukan. Ini 
adalah kerana jadual penentuan saiz sampel oleh Krejcie dan Morgan mempunyai aras keyakinan sebanyak 95\%. Berdasarkan jadual penentuan saiz sampel Krejcie dan Morgan, jika bilangan populasi adalah 169 orang maka saiz sampel adalah sebanyak 113-118 orang. Walau bagaimanapun, dalam kajian ini, saiz sampel ditetapkan sebanyak 120 orang. Cara pemilihan sampel dilakukan secara persampelan rawak mudah. Penyelidik tidak memberikan ciri-ciri tertentu dalam pemilihan sampel kajian. Semua populasi mempunyai peluang yang sama untuk dipilih sebagai sampel kepada kajian ini.

Sementara itu, borang soal selidik digunakan sebagai instrumen kajian untuk mendapatkan data. Instrumen yang digunakan ini telah diadaptasi daripada instrumen soal selidik yang terdapat dalam kajian Stevon (2012) serta Aitzaz Saeed dan Rehan (2008). Hal ini kerana instrumen yang diterjemah atau diadaptasi boleh dipertimbang sebagai instrumen yang baru dibina berdasarkan saranan Nunally dan Bernstein (1994).

\section{Dapatan Kajian}

Berdasarkan Jadual 1, keputusan analisis ujian Korelasi Pearson menunjukkan wujudnya korelasi positif yang signifikan iaitu $\mathrm{r}=.492$ dan $\mathrm{p}=.000$. Keputusan tersebut menunjukkan bahawa terdapat hubungan yang sederhana ( $\mathrm{r}=.492)$ antara bidang tugas harian guru tingkatan enam dengan penjenamaan semula pengurusan tingkatan enam. Hubungan positif menunjukkan kesan positif daripada bidang tugas harian guru tingkatan enam akan memberikan kesan kepada penjenamaan semula pengurusan tingkatan enam. Hasil analisis ini menunjukkan keputusan signifikan, $p<.05$. Oleh itu hipotesis nul yang menyatakan tidak terdapat hubungan yang signifikan bidang tugas harian guru tingkatan enam dengan penjenamaan semula pengurusan tingkatan enam adalah ditolak.

Jadual 1: Analisis Korelasi Pearson hubungan antara bidang tugas harian guru tingkatan enam dengan penjenamaan semula pengurusan tingkatan enam

\begin{tabular}{|c|c|c|c|}
\hline \multirow[b]{3}{*}{ Pemboleh ubah } & & \multicolumn{2}{|c|}{ Bidang Tugas Harian Penjenamaan Semula } \\
\hline & & Guru Tingkatan & Pengurusan \\
\hline & & Enam & Tingkatan Enam \\
\hline \multicolumn{2}{|c|}{ Bidang Tugas Harian Guru Korelasi Pearson } & 1 & $.492^{* *}$ \\
\hline \multirow[t]{2}{*}{ Tingkatan Enam } & Sig. (2-hujung) & & .000 \\
\hline & $\mathrm{N}$ & 120 & 120 \\
\hline Penjenamaan Semula & Korelasi Pearson & $.492^{* *}$ & 1 \\
\hline Pengurusan & Sig. (2-hujung) & .000 & \\
\hline Tingkatan Enam & $\mathrm{N}$ & 120 & 120 \\
\hline \multicolumn{4}{|c|}{ **. Correlation is significant at the 0.01 level (2-tailed). } \\
\hline
\end{tabular}

Sementara itu, berdasarkan Jadual 2, keputusan analisis ujian Korelasi Pearson menunjukkan wujudnya korelasi negatif dan tidak signifikan iaitu $\mathrm{r}=-.060$ dan $\mathrm{p}=.517$. Keputusan tersebut menunjukkan bahawa terdapat hubungan yang sangat lemah $(\mathrm{r}=-.060)$ antara hubungan sosial antara guru-guru di sekolah dengan penjenamaan semula pengurusan tingkatan enam. Hubungan kedua-dua pemboleh ubah adalah negatif. Hasil analisis ini menunjukkan keputusan tidak signifikan, p>.05. Oleh itu, hipotesis nul yang menyatakan tidak terdapat hubungan yang signifikan hubungan sosial antara guru-guru di sekolah dengan penjenamaan semula pengurusan tingkatan enam adalah gagal ditolak.

Jadual 2: Analisis Korelasi Pearson hubungan antara hubungan sosial antara guru-guru di sekolah dengan penjenamaan semula pengurusan tingkatan enam

\begin{tabular}{llll}
\hline & & $\begin{array}{l}\text { Hubungan Sosial Penjenamaan Semula } \\
\text { antara Guru- } \\
\text { Guru }\end{array}$ & $\begin{array}{l}\text { Pengurusan } \\
\text { Tingkatan Enam }\end{array}$ \\
\hline $\begin{array}{l}\text { Pemboleh ubah } \\
\text { Guru-Guru }\end{array}$ & $\begin{array}{l}\text { Korelasi Pearson } \\
\text { Sig. (2-hujung) }\end{array}$ & 1 & -.060 \\
& $\mathrm{~N}$ & 120 & .517 \\
\hline
\end{tabular}


Malaysian Journal of Social Sciences and Humanities (MJSSH), Volume 6, Issue 5, (page 35 - 44), 2021

DOI: https://doi.org/10.47405/mjssh.v6i5.800

\begin{tabular}{llll}
\hline Penjenamaan Semula & Korelasi Pearson & -.060 & 1 \\
Pengurusan & Sig. (2-hujung) & .517 & \\
Tingkatan Enam & $\mathrm{N}$ & 120 & 120 \\
\hline
\end{tabular}

\section{Kesimpulan}

Penyelidikan ini dilaksanakan untuk mengenal pasti hubungan antara bidang tugas harian guru tingkatan enam dan hubungan sosial antara guru-guru dengan penjenamaan semula pengurusan tingkatan enam di bahagian Sandakan. Berdasarkan analisis, terdapat hubungan yang signifikan antara bidang tugas harian guru tingkatan enam dengan penjenamaan semula pengurusan tingkatan enam. Walaupun penjenamaan semula tingkatan enam telah menyebabkan beban tugas bertambah, mereka tetap dapat melaksanakan perubahan bidang tugas harian guru tingkatan enam seperti penyediaan 4 folio, melaksanakan penilaian kerja kursus, membimbing kepimpinan pelajar melalui aktiviti kokurikulum dan menghasilkan penyelidikan setiap tahun. Hal ini menunjukkan guru-guru tingkatan enam di Bahagian Sandakan ini komited merealisasikan kejayaan penjenamaan semula tingkatan enam. Selain itu, hasil analisis menunjukkan tidak terdapat hubungan yang signifikan antara hubungan sosial antara guru-guru di sekolah dengan penjenamaan semula pengurusan tingkatan enam. Dapatan kajian ini menunjukkan bahawa majoriti guru tingkatan enam Bahagian Sandakan yang dilantik oleh KPM berusaha memelihara hubungan baik dengan pentadbir sekolah aliran perdana dan hubungan baik dengan rakan guru aliran perdana di sekolah melalui kerjasama, tolong-menolong dan hormat menghormati antara satu sama lain demi organisasi sekolah untuk mencapai produktiviti yang lebih baik, di samping dapat menyumbang kepada suasana yang cukup harmoni di sekolah. Hal ini dapat memastikan kejayaan transformasi tingkatan enam melalui penjenamaan semula tingkatan enam.

\section{Rujukan}

Ab. Aziz Yusof. (2002). Pengurusan Sumber Manusia: Konsep, Isu dan Pelaksanaan. Selangor: Prentice Hall, Pearson Malaysia Sdn. Bhd.

Afid Burhanuddin. (2014). Aplikasi Teori Z Dalam Pengelolaan Pendidikan, https://afidburhanuddin.wordpress.com/2014/01/20/aplikasi-teori-z-dalam-pengelolaanpendidikan/

Aitzaz Saeed \& Rehan Arshad. (2008). Corporate Branding and Customer's Purchase Preferences in Mobile Phone Telecommunication. Thesis. Halmstad University.

Ashari Sikor. (2011). Teknik Pembelajaran Andragogi Dalam Kalangan Pelajar Dewasa Di Institusi Pengajaran Tinggi Awam Kementerian Pengajian Tinggi Malaysia. Laporan Projek Fakulti Pendidikan, Universiti Tun Hussein Onn.

Bernard Burnes. (2004). Kurt Lewin and the Planned Approach to Change: A Re-appraisal. Journal of Management Studies, 41, 977-1001.

Fatimah Affendi. (2014). Tahap Kepuasan Kerja dan Komitmen Organisasi dalam kalangan Guru Kolej Vokasional: Pendekatan Structural Equation Model. Tesis. Universiti Tun Hussein Onn Malaysia.

Gold, Y., \& Roth, R.A. (1993). Teachers Managing Stress and Preventing Burnout: The Professional Health Solution. Washington, D.C.: The Falmer Press.

Herzberg, F. (1966). Work and The Nature of Man. New York: World Publishing.

Jabatan Pendidikan Negeri Sabah. (2014). Maklumat Jumlah Guru Tingkatan enam di Sabah 2019. Unit Naik Pangkat JPN, Sabah

Kamisah Osman, Zanaton Iksan, \& Lilia Halim. (2007). Sikap terhadap Sains dan Sikap Saintifik di kalangan Pelajar Sains. Jurnal Pendidikan, 32, 39-60.

Kementerian Pelajaran Malaysia. (2008). Pembangunan Pendidikan 2001-2010.

Kementerian Pendidikan Malaysia. 2013. Pelan Pembangunan Pendidikan Malaysia 2013-2025.

Kim, K.J. \& Tang, L. N. (2008). A Comparison of Full-time employees, Part-time Employees and Non-employed University Students. Journal of Management Psychology, 17(16), 44-467.

Krejcie, R.V \& Morgan, D.W. (1970). Determining Sample Size for Research Activities. Educational and Psychological Measurement, 30, 607-610. 
DOI: https://doi.org/10.47405/mjssh.v6i5.800

Musabbir Chowdhury. (2013). Making Canada's Smes More Productive. Business Journal, 1, 1-12.

Ouchi, W. G. (1981). Theory Z: How American Management Can Meet the Japanese Challenge. New York: Avon Books.

Philip, S. (1995). Building A High Performance Organization. Kidlington: Elseview Science Ltd.

Stevon Luntid. (2012). Amalan Guru Dalam Kokurikulum dan Hubungannya dengan Pengurusan Kokurikulum di Sekolah Rendah Pedalaman Daerah Beluran. Disertasi Sarjana. Universiti Malaysia Sabah.

Surat Pekeliling Ikhtisas KPM (2009). Bidang Tugas Guru Akademik, Guru Kokurikulum \& Guru Amali Tingkatan 6, 2009. Kementerian Pendidikan Malaysia.

Surat Pekeliling Ikhtisas KPM (2009). Garis Panduan Pengurusan Tingkatan Enam, 2009. Kementerian Pendidikan Malaysia. 